Review

\title{
Treatment for Hepatocellular Carcinoma in Elderly Patients: A Literature Review
}

\author{
Hiroki Nishikawa $^{\bowtie}$, Toru Kimura, Ryuichi Kita, Yukio Osaki \\ Department of Gastroenterology and Hepatology, Osaka Red Cross Hospital, Osaka, Japan.
}

$\triangle$ Corresponding author: Hiroki Nishikawa, MD, Department of Gastroenterology and Hepatology, Osaka Red Cross Hospital, 5-30 Fudegasaki-cho, Tennoji-ku, Osaka 543-0027, Japan. Tel: +81-6-6774-5111; Fax: +81-6-6774-5131 E-mail: h-nishikawa@osaka-med.jrc.or.jp.

() Ivyspring International Publisher. This is an open-access article distributed under the terms of the Creative Commons License (http://creativecommons.org/ licenses/by-nc-nd/3.0/). Reproduction is permitted for personal, noncommercial use, provided that the article is in whole, unmodified, and properly cited.

Received: 2013.07.29; Accepted: 2013.09.07; Published: 2013.09.14

\begin{abstract}
An aging society means that the number of elderly patients with cancer is predicted to rise in the future. Hepatocellular carcinoma (HCC) usually develops in patients with hepatitis B virus infection, hepatitis $C$ virus infection, or alcoholic liver disease. The risk of developing HCC is also known to be age-dependent and elderly patients sometimes present with HCC. The increased longevity of the population thus means that more elderly HCC patients are to be expected in the coming years. In general, many elderly patients are not receiving optimal therapy for malignancies, because it is often withheld from them because of perceived minimal survival advantage and the fear of potential toxicity. Comprehensive data with regard to treatment of elderly patients with $\mathrm{HCC}$ are currently limited. Furthermore, current guidelines for the management of HCC do not satisfy strategies according to age. Thus, there is urgent need for investigation of safety and clinical outcomes in elderly patients who receive therapy for HCC. In this review, we primarily refer to current knowledge of clinical characteristics and outcome in elderly patients with $\mathrm{HCC}$ who underwent different treatment approaches (i.e., surgical resection, liver transplantation, locoregional therapies, and molecular-targeting therapy).
\end{abstract}

Key words: Hepatocellular carcinoma, Elderly patients, Cancer treatment, Clinical characteristics; Clinical outcome.

\section{Introduction}

Hepatocellular carcinoma (HCC) ranks fifth among the most prevalent cancers worldwide, and is the third most common cause of cancer-related death. Therefore, it is a major global health problem [1-5]. Most cases of HCC are attributable to chronic liver disease resulting from chronic hepatitis $B$ virus (HBV) and hepatitis $C$ virus (HCV) infection [1-5]. A recent report by Chung et al. demonstrated that the HCC-related mortality rate in Japan has steadily increased over the past 50 years and $>30000$ patients died of HCC every year and the age at death increased [6].

An aging society means that the number of elderly patients with cancer is also predicted to rise in the future [7]. In Japan, 75-year-old men and women have an average expected life span of around 5 and 10 years, respectively, and Japan has the greatest longevity in the world [8]. The risk of developing HCC is known to be age-dependent, and patients aged $\geq 75$ years sometimes present with HCC $[9,10]$. The increased longevity of the population means that more elderly HCC patients are to be expected in the coming years. In Japan, the adjusted HCC mortality has increased in recent years [11]. Moreover, the average age of HCC patients in Japan is increasing as well as the proportion of elderly HCC patients [12]. In the United States, latest estimates suggest that HCC incidence peaks above the age of 70 years [13]. Notably, 
together with the increase in the average lifespan, the number of HCC patients who are very old (i.e. $>80$ years) has been steadily increasing [14].

The number of elderly patients with HCC is expected to increase partly because of the following epidemiological reasons: (1) the rising incidence of liver cirrhosis (LC) unrelated to hepatitis virus, such as non-alcoholic steatohepatitis (NASH)-related LC, which develops over a long period of time; and (2) the delayed effect of antiviral therapy, such as nucleoside analogs for chronic hepatitis B and interferon (IFN) for chronic hepatitis $C$, on the development of HCC $[3-5,15,16]$. In addition, HCV infection is generally acquired during adult life. The incidence of HCV infection is closely associated with age, although the total number of cases is gradually decreasing because of the effect of antiviral therapy and the screening for $\mathrm{HCV}$ antibody in blood donors [17-20]. In patients with $\mathrm{HCV}$ infection, old age is associated with more severe histological findings and the presence of LC [10]. One of the most essential issues in clinical settings lies in the increasing number of elderly patients with $\mathrm{HCV}$ infection. HCV infection thus constitutes a major part of the etiology in elderly patients with HCC.

The management of elderly patients with HCC is significantly more complicated than that of younger patients because of comorbidity including cardiovascular disease, respiratory disease, diabetes mellitus, renal dysfunction, and altered drug pharmacokinetics [21-34]. In general, many elderly patients are not receiving optimal therapy for malignancies, because it is often withheld because of perceived minimal survival advantage and the fear of potential toxicity [30-35].

The treatment of HCC has significantly improved in the past few decades. The current treatments for HCC with established efficacy include: (1) surgical resection (SR)/liver transplantation (LT); (2) transcatheter arterial chemoembolization (TACE); (3) percutaneous radiofrequency ablation (RFA); (4) percutaneous ethanol injection (PEI); (5) percutaneous microwave coagulation therapy (PMCT); and (6) molecular-targeted therapy (MTT; e.g., sorafenib) [1-5, 36-40]. The optimal therapy should be selected for individual patients with HCC based on the assessment of performance status (PS), tumor-related factors, liver-function-related factors and comorbidity $[1-5,36-40]$. However, current guidelines for the management of HCC do not satisfy strategies according to age [41, 42].

As described earlier, the proportion of elderly patients with HCC and their average age is increasing in Japan [6, 10-12]. These trends have led to a rising demand in our country for investigations related to clinical characteristics and outcomes of therapy in elderly patients with HCC. In this review, we mainly refer to current knowledge of clinical characteristics and outcome in elderly patients with HCC who underwent different treatment approaches (i.e., SR, LT, locoregional therapies and MTT).

\section{Clinical characteristics of HCC in elderly patients}

The clinical course of liver diseases in elderly patients may differ in several aspects from that in younger patients, although there are no liver diseases specific to those of advanced age [43]. The process of liver carcinogenesis in elderly patients seems to be a distinctive factor. In previous studies, elderly patients with HCC were more likely to be women [14, 21-34, 44]. This may have been associated with a larger female elderly population because of their longer life expectancy. In other words, the proportion of women in the population is known to gradually increase with age [8]. The peak age of HCC occurrence in women is delayed by around 5 years as compared with that in men [45]. Furthermore, in many studies, elderly patients with $\mathrm{HCC}$ were more likely to be $\mathrm{HCV}$ carriers $[14,21-33,44]$. This finding may be explained by the fact that most HBV carriers acquire the virus via vertical transmission in the perinatal period, whereas most HCV carriers are infected at a later stage in life. HCC is therefore manifested as one of the complications of $\mathrm{HCV}$ carriers much later than in HBV carriers $[14,21-33,44]$. The peak age of HCC occurrence thus varies considerably worldwide because of the different distribution of etiological factors. The average age at onset of HBV-related HCC is reported to be 10 years younger than that of HCV-related HCC [46].

Oishi et al. reported that the proportion of elderly HCC patients negative for both hepatitis B surface antigen and HCV antibody (NBNC-HCC) was larger than that of younger HCC patients [47]. Factors other than hepatitis virus or alcohol, or genetic disturbance may be related to the development of HCC in some elderly patients [47]. Patients with NASH-related HCC are more likely to be older than those with hepatitis-virus-related HCC [48, 49]. A large proportion of cases with cryptogenic LC represent end-stage liver disease of NASH [50]. The background liver disease in elderly patients with NBNC-HCC may thus be considerably related to NASH $[48,49]$.

The prevalence of a normal liver in elderly patients with HCC is reported to be higher than that in younger patients [24-33, 43]. These observations suggest that aging itself is a risk factor linked to liver 
carcinogenesis. A previous report revealed that the telomere length in the liver is shortened with the progression of liver fibrosis and/or aging, increasing the risk of HCC development [51]. Aberrant DNA methylation, which is observed in the normal aging process, may also be associated with HCC development in elderly patients [52]. A recent report by Miki et al. demonstrated that $\mathrm{HCV}$ patients who received a blood transfusion at an older age developed HCC sooner despite their lower grade of liver fibrosis than those at a younger age [46]. Their results also indicate that aging itself is a risk factor for HCC development.

Several studies reported that the number of HCC nodules in elderly patients was smaller than that in younger patients [24-34, 43, 53-55]. Multicentric liver carcinogenesis is associated with the degree of background liver fibrosis $[56,57]$. Less advanced liver fibrosis in elderly patients may explain these observations.

In summary, elderly patients with HCC are more likely to female and HCV carriers compared with younger patients. The degree of background liver fibrosis and tumor-related factors may differ considerably between the two groups. Aging is closely associated with liver carcinogenesis.

\section{SR}

Along with LT, SR is regarded as a curative treatment approach for resectable HCC $[2,4,5,15,16$, $41,42,58]$. Furthermore, with technical advancement in surgery for HCC, SR for elderly HCC patients has become safer [59]. Although there is no specific age limitation for surgery for HCC in Japan, elderly patients may have shorter long-term survival after surgery as compared with younger patients because of their expected life span $[8,24-33,53,60]$. SR for HCC in elderly patients thus deserves serious consideration. According to the European Association for the Study of the Liver (EASL) guidelines, SR is indicated in HCC patients with a single tumor not exceeding 2 $\mathrm{cm}$ in diameter, PS 0, Child-Pugh class A, and no portal hypertension [41]. SR is considered the initial first-line treatment for resectable HCC because of its generally good outcome, and the lack brain-dead liver donors in Japan [12]. There have been several studies regarding the outcome and safety in elderly patients with HCC treated with SR [24-33, 47, 53-55, 61, 62].

Sato et al. studied the mortality and complication rates for hepatectomy for HCC in a large sample, using a nationwide Japanese database [Diagnosis Procedure Combination (DPC) database] [61]. Their multivariate logistic regression analyses for in-hospital mortality after hepatectomy for HCC revealed that, with age $<60$ years as a reference, $60-69$ years [hazard ratio (HR), 2.12], 70-79 years (HR, 3.12) and $>80$ years $(H R, 2.48)$ were significantly associated with in-hospital mortality [61]. This suggested that increased age was closely associated with mortality in patients who underwent surgery for HCC.

Kaibori et al. retrospectively studied the clinicopathological data and outcomes for 333 patients aged $<70$ years and 155 aged $\geq 70$ years who underwent SR [55]. The overall survival (OS) rates at 3, 5 and 7 years were $69.7 \%, 57.3 \%$ and $44.0 \%$, respectively, in the younger group and $70.3 \%, 54.6 \%$ and $35.8 \%$ in the elderly group $(P=0.7940)$. The corresponding 3 -, 5- and 7-year disease-free survival (DFS) rates were $38.5 \%, 22.5 \%$ and $18.9 \%$, respectively, in the younger group and $29.9 \%, 21.1 \%$ and $18.1 \%$ in the elderly group $(P=0.1856)$. In terms of surgery-related complications, there was no significant difference in the two groups $(P=0.7614)$ [55]. They therefore concluded that clinical outcomes of SR for HCC were similar in younger and elderly patients with HCC [55].

In our comparative studies of clinical outcomes and safety between elderly patients who underwent curative SR $(\geq 75$ years, $\mathrm{n}=92)$ and younger patients ( $<75$ years, $\mathrm{n}=206$ ), the 1 -, 3 - and 5-year OS rates after surgery were $90.0 \%, 73.3 \%$ and $43.0 \%$, respectively, in the elderly group and $91.0 \%, 77.5 \%$ and $64.4 \%$ in the control group $(P=0.188)$. The corresponding recurrence-free survival (RFS) rates were $66.3 \%, 38.8 \%$ and $26.2 \%$, respectively, in the elderly group and $66.3 \%$, $38.8 \%$ and $22.2 \%$ in the control group ( $P=0.634)$. There was no significant difference between the two groups in terms of surgery-related serious adverse events (SAEs) $(P>0.999)$ [29]. Thus, we concluded that SR appears to be a safe and feasible procedure for the treatment of HCC in elderly patients.

Portolani et al. demonstrated in a multivariate analysis of 175 elderly HCC patients who received surgery that major resection was an adverse predictor linked to OS $(P=0.021)$ [62]. They concluded that major resection in elderly patients with HCC must be reserved for selected cases, although they claimed that limited liver resection is a valid option for the treatment of HCC in elderly patients.

Interestingly, there is one report from Japan regarding the outcome of repeat hepatectomy for recurrent HCC in elderly patients with HCC [34]. The authors reported that there was no significant difference in the incidence of postoperative complications or the duration of postoperative hospital stay between elderly ( $\geq 75$ years, $\mathrm{n}=33$ ) and younger $(<75$ years, $\mathrm{n}=$ $88)$ patients. The 3 -year OS rates for the younger and elderly groups were $83 \%$ and $73 \%$, respectively $(P=$ $0.51)$. The 3-year DFS rates for the younger and el- 
derly groups were $35 \%$ and $38 \%(P=0.88)$ [34]. Repeat hepatectomy may be a safe procedure in some elderly patients with HCC.

In summary, elderly patients with HCC who underwent SR had comparable prognosis compared with younger patients, and SR for elderly patients with HCC may be safe. Previous studies regarding comparison of survival of SR in elderly patients and younger patients are summarized in Table 1.

\section{LT}

LT is considered as an important treatment option in western countries even in patients with decompensated cirrhosis of various causes [4, 63-65]. Given the Milan criteria are satisfied, living-donor partial LT for the treatment of decompensated cirrhosis complicated with HCC has been covered by the national health insurance system in Japan since 2004 [66]. Living-donor LT is the major choice of treatment because of the shortage of brain-dead donors in Japan [4, 63-67].

There is an arbitrary age limit for LT because of the increased comorbidity in elderly patients [68]. In general, HCC patients aged $>65-70$ years are not considered as potential candidates for LT [69]. However, there are several data regarding clinical outcomes in elderly patients with or without HCC who underwent LT [60, 68-72].

Randell et al. reported that for LT recipients aged $>65$ years, the annual death rate per 1000 patients at risk rose from 49 in 1991 to 185 in 2000 [71]. They emphasized that although elderly patients should not be completely excluded as candidates for LT, careful consideration during the evaluation process is required. Zetterman et al. also demonstrated that recipient age was a significant predictor for survival in patients with HCV infection [72].

Table I. Previous studies regarding comparison of clinical outcomes in younger and elderly patients treated with surgical resection for hepatocellular carcinoma.

\begin{tabular}{|c|c|c|c|c|c|c|c|c|c|c|c|c|}
\hline \multirow[t]{2}{*}{$\begin{array}{l}\text { Author/ } \\
\text { year/country }\end{array}$} & \multirow[t]{2}{*}{ Treatment } & \multirow{2}{*}{$\begin{array}{l}\text { Definition } \\
\text { of elderly } \\
\text { patient }\end{array}$} & \multicolumn{2}{|c|}{$\begin{array}{l}\text { No. of } \\
\text { patient }\end{array}$} & \multicolumn{2}{|l|}{ OS } & \multicolumn{2}{|l|}{$\mathrm{R}(\mathrm{D}) \mathrm{FS}$} & \multicolumn{2}{|c|}{ Morbidity rate } & \multicolumn{2}{|c|}{$\begin{array}{l}\text { Mortality } \\
\text { rate }\end{array}$} \\
\hline & & & $\mathrm{Y}$ & $\mathrm{E}$ & $\mathrm{Y}$ & $\mathrm{E}$ & $\mathrm{Y}$ & $E$ & $\mathrm{Y}$ & $\mathrm{E}$ & $\mathrm{Y}$ & $\mathrm{E}$ \\
\hline $\begin{array}{l}\text { Takenaka et al } \\
\text { /1994/Japan [33] }\end{array}$ & Surgery & $\geq 70$ years & 229 & 39 & $\begin{array}{l}51.6 \% \\
\text { (5-year) }\end{array}$ & $\begin{array}{l}75.9 \% * * \\
\text { (5-year) }\end{array}$ & $\begin{array}{l}31.0 \% \\
\text { (5-year) }\end{array}$ & $\begin{array}{l}30.4 \% * * \\
\text { (5-year) }\end{array}$ & $\begin{array}{l}2 \% \\
\text { (LF } \\
\text { only) }\end{array}$ & $\begin{array}{l}10 \% * \\
\text { (LF } \\
\text { only) }\end{array}$ & $1.0 \%$ & $\begin{array}{l}5.0 \% * \\
*\end{array}$ \\
\hline $\begin{array}{l}\text { Poon et al } \\
\text { /1999/China [27] }\end{array}$ & Surgery & $\geq 70$ years & 299 & 31 & $\begin{array}{l}51 \% \\
\text { (3-year) }\end{array}$ & $\begin{array}{l}58 \% * * \\
\text { (3-year) }\end{array}$ & $\begin{array}{l}38 \% \\
\text { (3-year) }\end{array}$ & $\begin{array}{l}27 \% * * \\
\text { (3-year) }\end{array}$ & $40 \%$ & $48 \% * *$ & $6 \%$ & $\begin{array}{l}10 \% * \\
*\end{array}$ \\
\hline $\begin{array}{l}\text { Cescon et al } \\
\text { /2003/Italy [53] }\end{array}$ & Right hepatectomy & $\geq 70$ years & 99 & 23 & $\begin{array}{l}53.9 \% \\
\text { (3-year) }\end{array}$ & $\begin{array}{l}64.2 \% * * \\
\text { (3-year) }\end{array}$ & NA & NA & $32.3 \%$ & $39.1 \%$ ** & $2.0 \%$ & $0 \% * *$ \\
\hline $\begin{array}{l}\text { Yeh et al } \\
\text { /2004/Taiwan [28] }\end{array}$ & Surgery & $\geq 70$ years & 398 & 34 & $\begin{array}{l}45.5 \% \\
\text { (3-year) }\end{array}$ & $\begin{array}{l}64.3 \% * * \\
\text { (3-year) }\end{array}$ & $\begin{array}{l}26.5 \% \\
\text { (5-year) }\end{array}$ & $\begin{array}{l}28.7 \% * * \\
\text { (5-year) }\end{array}$ & NA & NA & $7.7 \%$ & $10.5^{* *}$ \\
\hline $\begin{array}{l}\text { Zhou et al. } \\
\text { /2006/China [30] }\end{array}$ & Surgery & $\geq 65$ years & 125 & 54 & $\begin{array}{l}49.1 \% \\
\text { (3-year) }\end{array}$ & $\begin{array}{l}56.8 \% * * \\
\text { (3-year) }\end{array}$ & $\begin{array}{l}33.8 \% \\
\text { (3-year) }\end{array}$ & $\begin{array}{l}36.0 \% * * \\
\text { (3-year) }\end{array}$ & NA & NA & $2.4 \%$ & $0 \% * *$ \\
\hline $\begin{array}{l}\text { Kondo et al } \\
\text { /2008/Japan [24] }\end{array}$ & Surgery & $\geq 70$ years & 199 & 95 & NA & $\mathrm{NA}^{* *}$ & NA & NA & $43.8 \%$ & $41.3 \% * *$ & NA & NA \\
\hline $\begin{array}{l}\text { Kaibori et al } \\
\text { /2009/Japan [55] }\end{array}$ & Surgery & $\geq 70$ years & 333 & 155 & $\begin{array}{l}69.7 \% \\
\text { (3-year) }\end{array}$ & $\begin{array}{l}70.3 \% \\
\text { (3-year) }\end{array}$ & $\begin{array}{l}38.5 \% \\
\text { (3-year) }\end{array}$ & $\begin{array}{l}29.9 \% * * \\
\text { (3-year) }\end{array}$ & $19 \%$ & $18 \% * *$ & $4 \%$ & $3 \% * *$ \\
\hline $\begin{array}{l}\text { Oishi et al } \\
\text { /2009/Japan [47] }\end{array}$ & Surgery & $\geq 75$ years & 504 & 62 & $\begin{array}{l}81 \% \\
\text { (3-year) }\end{array}$ & $\begin{array}{l}77 \% * * \\
\text { (3-year) }\end{array}$ & $\begin{array}{l}46 \% \\
\text { (3-year) }\end{array}$ & $\begin{array}{l}43 \%{ }^{* *} \\
\text { (3-year) }\end{array}$ & $19 \%$ & $22 \% * *$ & $1 \%$ & $0 \%$ \\
\hline $\begin{array}{l}\text { Huang et al } \\
\text { /2009/China [25] }\end{array}$ & Surgery & $\geq 70$ years & 268 & 67 & $\begin{array}{l}39.9 \% \\
\text { (3-year) }\end{array}$ & $\begin{array}{l}54.6 \% * \\
\text { (3-year) }\end{array}$ & $\begin{array}{l}40.8 \% \\
\text { (3-year) }\end{array}$ & $\begin{array}{l}57.7 \% * * \\
\text { (3-year) }\end{array}$ & $4.5 \%$ & $9 \% * *$ & $1.1 \%$ & $\begin{array}{l}1.5 \% * \\
*\end{array}$ \\
\hline $\begin{array}{l}\text { Shirabe et al } \\
\text { /2009/Japan [54] }\end{array}$ & Surgery & $\geq 80$ years & 43 & 307 & $\begin{array}{l}84.4 \% \\
\text { (2-year) }\end{array}$ & $\begin{array}{l}75.6 \% * * \\
\text { (2-year) }\end{array}$ & NA & NA & $22 \%$ & $26 \% * *$ & $0 \%$ & $\begin{array}{l}0.3 \% * \\
*\end{array}$ \\
\hline $\begin{array}{l}\text { Mirici-Cappa et al } \\
\text { /2009/Italy [32] }\end{array}$ & Surgery & $\geq 70$ years & 43 & 142 & $\begin{array}{l}61.6 \% \\
\text { (3-year) }\end{array}$ & $\begin{array}{l}67.3 \% * * \\
\text { (3-year) }\end{array}$ & NA & NA & NA & NA & NA & NA \\
\hline $\begin{array}{l}\text { Portolani et al } \\
\text { /2011/Italy [62] }\end{array}$ & Limited resection & $\geq 70$ years & 276 & 175 & NA & $\mathrm{NA}^{* *}$ & $\begin{array}{l}41.9 \% \\
\text { (3-year) }\end{array}$ & $\begin{array}{l}37.1 \% * * \\
\text { (3-year) }\end{array}$ & $16.7 \%$ & $16.0 \% * *$ & $4.2 \%$ & $\begin{array}{l}3.2 \% * \\
*\end{array}$ \\
\hline $\begin{array}{l}\text { Su et al } \\
\text { /2012/Taiwan [26] }\end{array}$ & Surgery & $\geq 55$ years & 700 & 374 & $\begin{array}{l}67.3 \% \\
\text { (3-year) }\end{array}$ & $\begin{array}{l}66.4 \% * \\
\text { (3-year) }\end{array}$ & NA & $\mathrm{NA}^{* *}$ & NA & NA & NA & NA \\
\hline $\begin{array}{l}\text { Nishikawa et al } \\
\text { /2013/Japan [29] }\end{array}$ & Surgery & $\geq 75$ years & 206 & 92 & $\begin{array}{l}77.5 \% \\
\text { (3-year) }\end{array}$ & $\begin{array}{l}73.3 \% * * \\
\text { (3-year) }\end{array}$ & $\begin{array}{l}38.8 \% \\
\text { (3-year) }\end{array}$ & $\begin{array}{l}38.8 \% * * \\
\text { (3-year) }\end{array}$ & $15.5 \%$ & $16.3 \% * *$ & NA & NA \\
\hline
\end{tabular}

OS; overall survival, R(D)FS; recurrence (disease)-free survival, Y; younger patients, E; elderly patients, LF; liver failure, NA; not available, * statistically significant, ${ }^{* *}$ statistically not significant. 
Taner et al. reported in 13 patients (aged $\geq 75$ years) who underwent orthotopic LT that there were no intraoperative or perioperative deaths and seven patients are still alive with a mean survival period of 65 months [68]. They concluded that advanced age itself is not considered a contraindication for LT. A recent report from Canada demonstrated in 822 patients who received deceased donor LT (197 donors aged $>60$ years) that HCV infection and recipient age were the only adverse predictors for graft and patient survival in those receiving an older graft [70].

With regard to LT for patients with HCC, a recent report from Switzerland revealed in 30 HCC patients experiencing post-transplant $\mathrm{HCC}$ recurrence that time from transplant to HCC recurrence $(P=$ $0.001)$ and history of rejection $(P=0.043)$ were independent predictors linked to post-recurrence survival, and advanced age was not a significant predictor associated with survival [60].

Overall, although LT for elderly patients is not always contraindicated, thoughtful consideration for LT and careful observation after LT are needed.

\section{Percutaneous treatment}

Since its introduction in Japan in 1999, RFA has rapidly gained popularity because of its excellent antitumor effect, safety and low invasiveness. Now, RFA is the first-line percutaneous treatment for HCC [1-5, 21, 39, 73-78]. The current EASL guidelines recommend percutaneous RFA for HCC with PS 0-2, Child-Pugh class A or B, and $\leq 3$ unresectable tumors of $\leq 3 \mathrm{~cm}$ diameter. Even in patients with unresectable tumors $>3 \mathrm{~cm}$, percutaneous RFA in combination with TACE is recommended to expand the ablated area [42, 79]. More recently, several investigators have used RFA to treat selected patients with resectable HCC with favorable clinical outcomes, and RFA is gradually gaining popularity in the treatment of resectable HCC in many countries, in addition to Japan [78].

In general, elderly patients have a high incidence of comorbidity such as cardiovascular disease, diabetes mellitus and chronic renal disease, and are considered high-risk patients for SR [22-34, 53-55, 62]. Thus, radical SR of HCC may be less feasible in elderly patients than in younger patients in several aspects, and RFA therapy may be an acceptable alternative [74-80].

Sato et al. studied the mortality and complication rates for RFA of HCC in a large sample, using a nationwide Japanese database (DPC) [61]. Their multivariate logistic regression analyses for in-hospital mortality after RFA for HCC revealed that, with age $<69$ years as a reference, 70-79 years (HR, 7.05) and
$>80$ years $(\mathrm{HR}, 8.12)$ were significantly associated with in-hospital mortality. This suggested that increased age was closely associated with mortality in patients who underwent RFA for HCC, as well as in those who underwent surgery.

Shiina et al. conducted a large single-center retrospective study involving 1170 HCC patients [269 $(23.0 \%)>75$ years old] who underwent RFA [76]. In their multivariate analysis, increasing age was significantly associated with OS [HR, 1.03; 95\% confidence interval (CI), 1.02-1.04; $P<0.0001$ ) [76].

Takahashi et al. conducted a retrospective comparative study between younger ( $<75$ years, $n=354$ ) and elderly $(\geq 75$ years, $n=107)$ patients who underwent curative RFA [22]. The cumulative OS rates at 3 and 5 years were $82 \%$ and $61 \%$, respectively, in the elderly group and $80 \%$ and $63 \%$ in the younger group $(P=0.824)$. The cumulative RFS rates were $49 \%$ at 3 years in the elderly group and $49 \%$ at 3 years in the younger group $(P=0.594)$. The major complication rates were $2.8 \%(3 / 107)$ in the elderly group and $3.67 \%(13 / 354)$ in the younger group. They concluded that RFA treatment might be safe and effective in elderly patients, as well as younger HCC patients [22]. In our recent comparative study $(\mathrm{n}=368$ : $130 \mathrm{HCC}$ patients aged $\geq 75$ years and 238 HCC patients aged $<75$ years), the 1 - and 3-year OS rates after RFA were 90.0 and $64.1 \%$, respectively, in the elderly group, and 97.6 and $83.7 \%$ in the younger group $(P=0.001)$ [21]. The corresponding RFS rates after RFA were $66.9 \%$ and $21.3 \%$, respectively, in the elderly group and $80.5 \%$ and $40.0 \%$ in the younger group $(P=0.001)$. The 1 - and 3-year local tumor progression rates after RFA were $15.0 \%$ and $43.0 \%$, respectively, in the elderly group and $8.3 \%$ and $26.3 \%$ in the younger group $(P=$ $0.002)$. In terms of SAEs related to RFA, there was no significant difference between these two groups $(P=$ 0.670). We concluded that clinical outcomes in the elderly group were poorer than those in the younger group, although RFA in the elderly patients was a safe procedure.

Overall, whether elderly patients with HCC treated with ablative therapies have comparable clinical outcomes as compared with younger patients remains controversial. Previous reports with regard to comparison of survival of ablative therapies in elderly patients and younger patients are summarized in Table 2 .

\section{TACE}

TACE is a procedure whereby an embolizing agent after intra-arterial injection of an anticancer drug is injected into the hepatic artery to deprive the 
tumor of its major nutrient source via embolization of the nutrient artery, resulting in ischemic necrosis of the tumor [81-88]. TACE is the most frequently used treatment for unresectable HCC in Japan where it was originally developed [82, 85-88]. The EASL guidelines recommend TACE for unresectable, Child-Pugh class A or B multiple HCC with no vascular invasion, whereas in Japan, TACE is recommended even for HCC patients with vascular invasion if radiological portal invasion $(\mathrm{Vp})$ is $\mathrm{Vp} 1$ or $\mathrm{Vp} 2$ [41, 42].

Previously, old age was considered to be a contraindication for TACE in the treatment of HCC [89]. However, a recent study demonstrated that the prognostic factors affecting the survival of HCC patients treated with TACE included: (1) tumor stage; (2) tumor markers; and (3) hepatic functional reserve [82]. Advanced age was not an adverse predictor in patients with HCC treated with TACE.

Yau et al. conducted a large comparative study in 1040 HCC patients treated with TACE (197 aged $\geq 70$ years and $843<70$ years) [44]. Both the overall median survival (14.0 vs. 8.1 months, $P<0.003)$ and disease-specific survival (15.2 vs. 8.7 months, $P<$ 0.001 ) were significantly higher in elderly than young patients and no significant difference was observed in terms of TACE-related mortality between the young and elderly patients ( $3 \%$ vs. $4 \%, P=0.49)$. They concluded that elderly patients with HCC treated with
TACE had comparable efficacy and tolerability to those in younger patients.

Likewise, Cohen et al. conducted a prospective cohort study regarding TACE for HCC including 102 HCC patients ( 34 aged $\leq 65$ years, 45 aged $65-75$ years, and 23 aged $\geq 75$ years) [14]. Their results revealed that OS rates at 1, 2 and 3 years were $74 \%, 37 \%$ and $31 \%$, respectively, in patients aged $<65$ years; $83 \%$, $66 \%$ and $48 \%$ in patients aged $65-75$ years; and $86 \%$, $41 \%$ and $23 \%$ in patients aged $\geq 75$ years $(P=0.19)$. Advanced age was not associated with the rate of adverse events.

A recent study from Italy compared the outcomes among elderly $(\geq 70$ years, $n=128)$ and younger patients ( $<70$ years, $\mathrm{n}=197$ ) with unresectable HCC who received radioembolization [90]. It demonstrated that radioembolization was equally well tolerated in the two groups and there was no significant difference in survival between the two groups $(P=0.942)$. This suggested that radioembolization is well-tolerated and effective for elderly as well as younger patients.

Overall, elderly patients with unresectable HCC treated with TACE had comparable clinical outcomes compared with younger patients and TACE for elderly patients with unresectable HCC seems to be a safe procedure. Previous studies comparing survival of TACE for HCC in elderly and younger patients are summarized in Table 2.

Table 2. Reports of previous studies regarding of comparison of clinical outcomes in younger and elderly patients treated with locoregional therapies for hepatocelluar carcinoma.

\begin{tabular}{|c|c|c|c|c|c|c|c|c|c|c|c|c|c|}
\hline \multirow[t]{2}{*}{$\begin{array}{l}\text { Author } \\
\text { /year/country }\end{array}$} & \multirow[t]{2}{*}{$\begin{array}{l}\text { Treat- } \\
\text { ment }\end{array}$} & \multirow[t]{2}{*}{$\begin{array}{l}\text { Child- } \\
\text { Pugh }\end{array}$} & \multirow{2}{*}{$\begin{array}{l}\text { Definition of } \\
\text { elderly pa- } \\
\text { tient }\end{array}$} & \multicolumn{2}{|c|}{ No. of patient } & \multicolumn{2}{|l|}{ OS } & \multicolumn{2}{|l|}{$\mathrm{R}(\mathrm{D}) \mathrm{FS}$} & \multicolumn{2}{|c|}{$\begin{array}{l}\text { Morbidity } \\
\text { rate }\end{array}$} & \multicolumn{2}{|c|}{$\begin{array}{l}\text { Mortality } \\
\text { rate }\end{array}$} \\
\hline & & & & $Y$ & $\mathrm{E}$ & $Y$ & $\mathrm{E}$ & $\mathrm{Y}$ & $\mathrm{E}$ & $\mathrm{Y}$ & $\mathrm{E}$ & $\mathrm{Y}$ & E \\
\hline $\begin{array}{l}\text { Tateishi et al } \\
\text { /2005/Japan [77] }\end{array}$ & RFA & $\mathrm{A} / \mathrm{B}$ & $\geq 68$ years & 160 & 159 & $\begin{array}{l}79.2 \% \\
\text { (3-year) }\end{array}$ & $\begin{array}{l}76 \% * * \\
\text { (3-year) }\end{array}$ & NA & NA & NA & NA & NA & NA \\
\hline $\begin{array}{l}\text { Takahashi et al } \\
\text { /2010/Japan [22] }\end{array}$ & RFA & $\mathrm{A} / \mathrm{B}$ & $\geq 75$ years & 354 & 107 & $\begin{array}{l}80 \% \\
\text { (3-year) }\end{array}$ & $\begin{array}{l}82 \% * * \\
\text { (3-year) }\end{array}$ & $\begin{array}{l}49 \% \\
\text { (3-year) }\end{array}$ & $\begin{array}{l}49 \% * * \\
\text { (3-year) }\end{array}$ & $3.7 \%$ & $2.8 \% * *$ & $0 \%$ & $0 \%$ ** \\
\hline $\begin{array}{l}\text { Mirici-Cappa et al } \\
\text { /2010/Italy [32] }\end{array}$ & $\begin{array}{l}\text { RFA or } \\
\text { PEI }\end{array}$ & $\mathrm{A} / \mathrm{B} / \mathrm{C}$ & $\geq 70$ years & 230 & 195 & $\begin{array}{l}52.9 \% \\
\text { (3-year) }\end{array}$ & $\begin{array}{l}53.4 \% * * \\
\text { (3-year) }\end{array}$ & NA & NA & NA & NA & NA & NA \\
\hline $\begin{array}{l}\text { Kao et al } \\
\text { /2012/Taiwan [23] }\end{array}$ & RFA & $\mathrm{A} / \mathrm{B}$ & $\geq 65$ years & 100 & 158 & $\begin{array}{l}87 \% \\
\text { (3-year) }\end{array}$ & $\begin{array}{l}83.1 \% * \\
\text { (3-year) }\end{array}$ & $\begin{array}{l}39.8 \% \\
\text { (3-year) }\end{array}$ & $\begin{array}{l}21.9 \% * \\
\text { (3-year) }\end{array}$ & NA & NA & NA & NA \\
\hline $\begin{array}{l}\text { Nishikawa et al } \\
\text { /2012/Japan [21] }\end{array}$ & RFA & $\mathrm{A} / \mathrm{B}$ & $\geq 75$ years & 238 & 130 & $\begin{array}{l}83.7 \% \\
\text { (3-year) }\end{array}$ & $\begin{array}{l}64.1 \% * \\
\text { (3-year) }\end{array}$ & $\begin{array}{l}40.0 \% \\
\text { (3-year) }\end{array}$ & $\begin{array}{l}21.3 \% * \\
\text { (3-year) }\end{array}$ & $1.3 \%$ & $2.3 \% * *$ & $0 \%$ & $0 \%$ ** \\
\hline $\begin{array}{l}\text { Poon et al } \\
\text { /1999/China [27] }\end{array}$ & TACE & $\mathrm{A} / \mathrm{B}$ & $\geq 70$ years & 317 & 67 & $\begin{array}{l}18 \% \\
\text { (3-year) }\end{array}$ & $\begin{array}{l}25 \% * * \\
\text { (3-year) }\end{array}$ & NA & NA & $26 \%$ & $24 \% * *$ & $5 \%$ & $7 \% * *$ \\
\hline $\begin{array}{l}\text { Yau et al } \\
\text { /2009/China [44] }\end{array}$ & TACE & $\mathrm{A} / \mathrm{B} / \mathrm{C}$ & $\geq 70$ years & 843 & 197 & $\begin{array}{l}14.9 \% \\
\text { (3-year) }\end{array}$ & $\begin{array}{l}23.2 \% * \\
\text { (3-year) }\end{array}$ & NA & NA & $27 \%$ & $24 \% * *$ & $3.5 \%$ & $\begin{array}{l}4.7 \% \\
* *\end{array}$ \\
\hline $\begin{array}{l}\text { Mirici-Cappa et al } \\
\text { /2010/Italy [32] }\end{array}$ & TACE & $\mathrm{A} / \mathrm{B} / \mathrm{C}$ & $\geq 70$ years & 396 & 158 & $\begin{array}{l}32.0 \% \\
\text { (3-year) }\end{array}$ & $\begin{array}{l}36.4 \% * * \\
\text { (3-year) }\end{array}$ & NA & NA & NA & NA & NA & NA \\
\hline $\begin{array}{l}\text { Cohen et al } \\
\text { /2013/Israel [14] }\end{array}$ & TACE & $\mathrm{A} / \mathrm{B} / \mathrm{C}$ & $\geq 75$ years & $\begin{array}{l}38(<65 \mathrm{yr}) / \\
41(65-75 \mathrm{yr})\end{array}$ & 23 & $\begin{array}{l}31 \% / \\
48 \% \\
\text { (3-year) }\end{array}$ & $\begin{array}{l}23 \% * * \\
\text { (3-year) }\end{array}$ & NA & NA & NA & NA & NA & NA \\
\hline
\end{tabular}

OS; overall survival, R(D)FS; recurrence (disease)-free survival, Y; younger patients, E; elderly patients, RFA; radiofrequency ablation, PEI; percutaneous ethanol injection, TACE; transcatheter arterial chemoembolization, NA; not available, * statistically significant, ${ }^{* *}$ statistically not significant. 


\section{Molecular-targeted therapy (sorafenib)}

There has long been a lack of concrete evidence to support systemic chemotherapy for unresectable advanced HCC [91]. However, after the clinical efficacy of a molecular-targeted drug, sorafenib, for unresectable advanced HCC was shown in two RCTs (SHARP trial and Asia-Pacific trial), this drug was approved for the treatment of unresectable advanced HCC in Japan in 2009 [92, 93]. The EASL guidelines recommend sorafenib for unresectable, advanced, Child-Pugh class A or B HCC with PS 0-2 and vascular invasion or distant metastasis [41]. According to the Japanese guidelines, sorafenib is recommended for unresectable, advanced, Child-Pugh class A HCC with vascular invasion or distant metastasis, as well as for patients intolerant to TACE or in whom the procedure of TACE is anatomically unsuitable $[42,94$, 95].

Systemic chemotherapy for advanced cancer is often either modified or withheld for the management of elderly patients with advanced cancer for fear of potential toxicity [96-98]. Furthermore, several adverse events associated with sorafenib have been reported [92-95, 99-105]. Especially in elderly patients with advanced HCC who undergo sorafenib therapy, caution is needed for the expected SAEs, because they have higher comorbidity and poorer PS, and SAEs cause treatment discontinuation [96-98].

Wong et al. compared the efficacy and tolerability of sorafenib elderly (age $\geq 70$ years, $n=37$ ) and younger (age $<70$ years, $n=135$ ) patients with advanced HCC [96]. The median progression-free survival time was similar in the elderly and younger groups (2.99 months vs. 3.09 months; $P=0.275)$, as was the OS time (5.32 months vs. 5.16 months; $P=$ $0.310)$. Grade 3 or 4 SAEs were observed in $68.6 \%$ of the elderly and $62.7 \%$ of the younger patients $(P=$ $0.560)$. They concluded that the survival benefits and overall treatment-related SAEs of sorafenib are comparable in elderly and younger patients with advanced HCC. Likewise, a study from Italy investigated the impact of age on the effects of sorafenib therapy in patients with HCC and LC [97]. In 150 patients [90 in the younger group ( $<70$ years) and 60 in the elderly group ( $\geq 70$ years)], the median time to progression (TTP) and OS were longer in the elderly than the younger group (12 vs. 8 months and 16 vs. 12 months, respectively), although the differences were not significant. Grade 3 and 4 SAEs were more frequent in the younger than the older group $(15.7 \%$ vs. $9.2 \%$, respectively; $P=0.0146$ ), suggesting that elderly patients with HCC and LC tolerate sorafenib therapy compared with younger patients with HCC and LC.
On the contrary, Morimoto et al. reported that the discontinuation rate of sorafenib therapy for advanced HCC because of SAEs was more frequent among patients aged $\geq 75$ years $(41.7 \%)$ than among those aged $<75$ years $(15.0 \%)$ with the standard dose of sorafenib ( $800 \mathrm{mg}$ daily) $(P=0.047)$ [106].

There is one report about the usefulness of a reduced starting dose of sorafenib in elderly patients with advanced HCC [98]. In 60 elderly patients with HCC aged $\geq 70$ years who received reduced dose sorafenib, median TTP was 7.0 months (95\% CI, 5.2-8.7 months) and median survival was 10.0 months (95\% CI, 5.0-14.9 months). Quality of life did not show any significant change during the study. The results emphasized the usefulness of reduced dose sorafenib in elderly patients with HCC.

However, there is still a lack of sufficient evidence of clinical usefulness and safety of sorafenib therapy in elderly patients with advanced HCC. Further cumulative clinical evidence is needed.

\section{Conclusion}

We reviewed the clinical characteristics and outcomes of each therapy in elderly patients with HCC. Etiology of background liver disease, male to female ratio, degree of liver fibrosis, proportion of patients with comorbidity, and tumor characteristics differ considerably between elderly and younger patients with HCC. In each therapy for HCC, that is, SR, LT, ablative therapies, TACE and MTT, some elderly patients with HCC may have comparable clinical outcomes and safety compared with younger patients. However, further clinical evidence is needed to confirm these results.

\section{Acknowledgment}

The authors would like to thank all the staff in our department for their valuable support.

\section{Conflict of interest}

The authors have not received any financial support for this article and have no conflicts of interest to declare.

\section{References}

1. Kudo M. Radiofrequency ablation for hepatocellular carcinoma: updated review in 2010. Oncology 2010; 78: 113-24.

2. Livraghi T, Mäkisalo H, Line PD. Treatment options in hepatocellular carcinoma today. Scand J Surg 2011; 100: 22-9.

3. El-Serag HB. Epidemiology of viral hepatitis and hepatocellular carcinoma. Gastroenterology 2012; 142: 1264-73.

4. de Lope CR, Tremosini S, Forner A, et al. Management of HCC. J Hepatol 2012; 56 Suppl 1: S75-S87.

5. El-Serag HB. Hepatocellular carcinoma. N Engl J Med 2011; 365(12): 1118-27.

6. Chung H, Ueda T, Kudo M. Changing trends in hepatitis C infection over the past 50 years in Japan. Intervirology. 2010; 53(1): 39-43. 
7. Hankey BF, Ries LA, Kosary CL,et al. Partitioning linear trends in age-adjusted rates. Cancer Causes Control 2000; 11:31-35.

8. [Internet] Ministry of Health. Labour and Welfare. Abridged life tables for Japan 2006. http://www.mhlw.go.jp/english/database/db-hw/ lifetb06/index.html.

9. Cho SJ, Yoon JH, Hwang SS, et al. Do young hepatocellular carcinoma patients with relatively good liver function have poorer outcomes than elderly patients? J Gastroenterol Hepatol 2007; 22: 1226-1231.

10. Asahina $\mathrm{Y}$, Tsuchiya $\mathrm{K}$, Tamaki N, et al. Effect of aging on risk for hepatocellular carcinoma in chronic hepatitis $\mathrm{C}$ virus infection. Hepatology 2010; 52: 518-527.

11. Kiyosawa K, Tanaka E. Characteristics of hepatocellular carcinoma in Japan. Oncology 2002; 62 Suppl 1: 5-7.

12. Ikai I, Arii S, Okazaki M, et al: The Liver Cancer Study Group of Japan, Kyoto, Japan. Report of the 17th Nationwide Follow-up Survey of Primary Liver Cancer in Japan. Hepatol Res 2007; 37: 676-691.

13. Nordenstedt H, White DL, El-Serag HB. The changing pattern of epidemiology in hepatocellular carcinoma. Dig Liver Dis. 2010; 42 Suppl 3: S206-S214

14. Cohen MJ, Bloom AI, Barak O, et al. Trans-arterial chemo-embolization is safe and effective for very elderly patients with hepatocellular carcinoma. World J Gastroenterol. 2013; 19(16): 2521-8

15. Llovet JM, Burroughs A, Bruix J. Hepatocellular carcinoma. Lancet 2003; 362(9399): 1907-17.

16. Rahbari NN, Mehrabi A, Mollberg NM, et al. Hepatocellular carcinoma: current management and perspectives for the future. Ann Surg 2011; 253(3): 453-69.

17. Tanaka J, Kumagai J, Katayama K, et al. Sex- and age-specific carriers of hepatitis $\mathrm{B}$ and $\mathrm{C}$ viruses in Japan estimated by the prevalence in the 3,485,648 first-time blood donors during 1995-2000. Intervirology. 2004; 47(1): 32-40.

18. Wyles DL. Antiviral resistance and the future landscape of hepatitis $C$ virus infection therapy. J Infect Dis. 2013; 207 Suppl 1: S33-9.

19. Cobb B, Pockros PJ, Vilchez RA, et al. HCV RNA viral load assessments in the era of direct-acting antivirals. Am J Gastroenterol. 2013; 108(4): 471-5.

20. Asselah T, Marcellin P. Interferon free therapy with direct acting antivirals for HCV. Liver Int. 2013; 33 Suppl 1: 93-104.

21. Nishikawa H, Osaki $\mathrm{Y}$, Iguchi E, et al. Percutaneous radiofrequency ablation for hepatocellular carcinoma: clinical outcome and safety in elderly patients. J Gastrointestin Liver Dis 2012; 21(4): 397-405.

22. Takahashi H, Mizuta T, Kawazoe S, et al. Efficacy and safety of radiofrequency ablation for elderly hepatocellular carcinoma patients. Hepatol Res. 2010; 40(10): 997-1005

23. Kao WY, Chiou YY, Hung HH, et al. Younger hepatocellular carcinoma patients have better prognosis after percutaneous radiofrequency ablation therapy. J Clin Gastroenterol. 2012; 46(1): 62-70.

24. Kondo K, Chijiiwa K, Funagayama M, et al. Hepatic resection is justified for elderly patients with hepatocellular carcinoma. World J Surg. 2008; 32(10): 2223-9.

25. Huang J, Li BK, Chen GH, et al. Long-term outcomes and prognostic factors of elderly patients with hepatocellular carcinoma undergoing hepatectomy. J Gastrointest Surg. 2009; 13(9): 1627-35.

26. Su CW, Lei HJ, Chau GY, et al. The effect of age on the long-term prognosis of patients with hepatocellular carcinoma after resection surgery: a propensity score matching analysis. Arch Surg. 2012; 147(2): 137-44

27. Poon RT, Fan ST, Lo CM, et al. Hepatocellular carcinoma in the elderly: results of surgical and nonsurgical management. Am J Gastroenterol. 1999; 94(9): 2460-6

28. Yeh CN, Lee WC, Jeng LB, et al. Hepatic resection for hepatocellular carcinoma in elderly patients. Hepatogastroenterology. 2004; 51(55): 219-23.

29. Nishikawa H, Arimoto A, Wakasa T, et al. Surgical resection for hepatocellular carcinoma: clinical outcomes and safety in elderly patients. Eur J Gastroenterol Hepatol. 2013; [Epub ahead of print]

30. Zhou L, Rui JA, Wang SB, et al. Clinicopathological features, post-surgical survival and prognostic indicators of elderly patients with hepatocellular carcinoma. Eur J Surg Oncol. 2006; 32(7): 767-72.

31. Reddy SK, Barbas AS, Turley RS, et al. Major liver resection in elderly patients: a multi-institutional analysis. J Am Coll Surg. 2011; 212(5): 787-95.

32. Mirici-Cappa F, Gramenzi A, Santi V, et al; Italian Liver Cancer Group. Treatments for hepatocellular carcinoma in elderly patients are as effective as in younger patients: a 20-year multicentre experience. Gut. 2010; 59(3): 387-96.

33. Takenaka $\mathrm{K}$, Shimada $\mathrm{M}$, Higashi $\mathrm{H}$, et al. Liver resection for hepatocellular carcinoma in the elderly. Arch Surg. 1994; 129(8): 846-50.
34. Tsujita E, Utsunomiya $\mathrm{T}$, Ohta $\mathrm{M}$, et al. Outcome of repeat hepatectomy in patients with hepatocellular carcinoma aged 75 years and older. Surgery. 2010; 147(5): 696-703.

35. Earle CC, Venditti LN, Neumann PJ, et al. Who gets chemotherapy for metastatic lung cancer? Chest. 2000; 117: 1239-1246.

36. Mazzaferro V, Regalia E, Doci R, et al. Liver transplantation for the treatment of small hepatocellular carcinomas in patients with cirrhosis. N Engl J Med 1996; 334(11): 693-9.

37. Zhou WP, Lai EC, Li AJ, et al. A prospective, randomized, controlled trial of preoperative transarterial chemoembolization for resectable large hepatocellular carcinoma. Ann Surg 2009; 249(2): 195-202.

38. Nishikawa $\mathrm{H}$, Arimoto A, Wakasa T, et al. Effect of transcatheter arterial chemoembolization prior to surgical resection for hepatocellular carcinoma. Int J Oncol 2013; 42(1): 151-60.

39. Nishikawa H, Osaki Y, Iguchi E, et al. Percutaneous radiofrequency ablation therapy for recurrent hepatocellular carcinoma. Anticancer Res 2012; 32(11): 5059-65.

40. Nishikawa H, Osaki Y, Kita R, et al. Transcatheter arterial infusion chemotherapy prior to radiofrequency thermal ablation for single hepatocellular carcinoma reduces the risk of intrahepatic distant recurrence. Int J Oncol 2012; 41(3): 903-9.

41. European Association For The Study Of The Liver; European Organisation For Research And Treatment Of Cancer. EASL-EORTC clinical practice guidelines: management of hepatocellular carcinoma. J Hepatol 2012; 56(4): 908-43.

42. Kudo M, Izumi N, Kokudo N, et al; HCC Expert Panel of Japan Society of Hepatology. Management of hepatocellular carcinoma in Japan: Consensus-Based Clinical Practice Guidelines proposed by the Japan Society of Hepatology (JSH) 2010 updated version. Dig Dis 2011; 29(3): 339-64.

43. Honda T, Miyaaki H, Ichikawa T, et al. Clinical characteristics of hepatocellular carcinoma in elderly patients. Oncol Lett. 2011; 2(5): 851-854.

44. Yau T, Yao TJ, Chan P, et al. The outcomes of elderly patients with hepatocellular carcinoma treated with transarterial chemoembolization. Cancer. 2009; 115(23): 5507-15.

45. El-Serag HB, Rudolph KL. Hepatocellular carcinoma: epidemiology and molecular carcinogenesis. Gastroenterology. 2007; 132(7): 2557-76.

46. Miki D, Aikata H, Uka K, et al. Clinicopathological features of elderly patients with hepatitis $C$ virus-related hepatocellular carcinoma. J Gastroenterol. 2008; 43(7): 550-7.

47. Oishi K, Itamoto T, Kobayashi T, et al. Hepatectomy for hepatocellular carcinoma in elderly patients aged 75 years or more. J Gastrointest Surg. 2009; 13(4): 695-701.

48. Ascha MS, Hanouneh IA, Lopez R, et al. The incidence and risk factors of hepatocellular carcinoma in patients with nonalcoholic steatohepatitis. Hepatology. 2010; 51(6): 1972-8

49. Yasui K, Hashimoto E, Tokushige K, et al; The Japan NASH Study Group. Clinical and pathological progression of non-alcoholic steatohepatitis to hepatocellular carcinoma. Hepatol Res. 2012; 42(8): 767-773.

50. Neuschwander-Tetri BA, Caldwell SH. Nonalcoholic steatohepatitis: summary of an AASLD Single Topic Conference. Hepatology. 2003; 37(5): 1202-19.

51. Isokawa $\mathrm{O}$, Suda $\mathrm{T}$, Aoyagi $\mathrm{Y}$, et al. Reduction of telomeric repeats as a possible predictor for development of hepatocellular carcinoma: convenient evaluation by slot-blot analysis. Hepatology. 1999; 30(2): 408-12.

52. Ahuja N, Li Q, Mohan AL, et al. Aging and DNA methylation in colorectal mucosa and cancer. Hepatol Res. 2012; 42(8): 767-773.

53. Cescon M, Grazi GL, Del Gaudio M, et al. Outcome of right hepatectomies in patients older than 70 years. Arch Surg. 2003; 138(5): 547-52.

54. Shirabe K, Kajiyama K, Harimoto N, et al. Early outcome following hepatic resection in patients older than 80 years of age. World J Surg. 2009; 33(9): 1927-32.

55. Kaibori M, Matsui K, Ishizaki M, et al. Hepatic resection for hepatocellular carcinoma in the elderly. J Surg Oncol. 2009; 99(3): 154-60.

56. Nishikawa H, Osaki Y, Iguchi E, et al. The effect of long-term supplementation with branched-chain amino acid granules in patients with hepatitis $\mathrm{C}$ virus-related hepatocellular carcinoma after radiofrequency thermal ablation. J Clin Gastroenterol. 2013; 47(4): 359-66.

57. Mazzaferro V, Romito R, Schiavo M, et al; HCC Italian Task Force. Prevention of hepatocellular carcinoma recurrence with alpha-interferon after liver resection in HCV cirrhosis. Hepatology. 2006; 44(6): 1543-54.

58. Makuuchi M, Sano K. The surgical approach to HCC: our progress and results in Japan. Liver Transpl 2004; 10(2 Suppl 1): S46-52.

59. Ishizawa T, Mise $Y$, Aoki $T$, et al. Surgical technique: new advances for expanding indications and increasing safety in liver resection for HCC: the Eastern perspective. J Hepatobiliary Pancreat Sci. 2010; 17(4): 389-93. 
60. Toso C, Cader S, Mentha-Dugerdil A, et al. Factors predicting survival after post-transplant hepatocellular carcinoma recurrence. J Hepatobiliary Pancreat Sci. 2013; 20(3): 342-7.

61. Sato M, Tateishi R, Yasunaga H, et al. Mortality and morbidity of hepatectomy, radiofrequency ablation, and embolization for hepatocellular carcinoma: a national survey of 54,145 patients. J Gastroenterol. 2012; 47(10): 1125-33.

62. Portolani N, Baiocchi GL, Coniglio A, et al. Limited liver resection: a good indication for the treatment of hepatocellular carcinoma in elderly patients. Jpn J Clin Oncol. 2011; 41(12): 1358-65.

63. Forner A, Reig ME, de Lope CR, et al. Current strategy for staging and treatment: the BCLC update and future prospects. Semin Liver Dis 2010; 30(1): 61-74.

64. Clavien PA, Lesurtel M, Bossuyt PM, et al; OLT for HCC Consensus Group. Recommendations for liver transplantation for hepatocellular carcinoma: an international consensus conference report. Lancet Oncol 2012; 13(1): e11-22.

65. Tsochatzis EA, Bosch J, Burroughs AK. New therapeutic paradigm for patients with cirrhosis. Hepatology 2012; 56(5): 1983-92.

66. Sugawara Y, Makuuchi M. Living donor liver transplantation: present status and recent advances. Br Med Bull 2006; 75-76: 15-28.

67. Sugawara Y, Makuuchi M. Advances in adult living donor liver transplantation: a review based on reports from the 10th anniversary of the adult-to-adult living donor liver transplantation meeting in Tokyo. Liver Transpl 2004; 10(6): 715-20.

68. Taner CB, Ung RL, Rosser BG, et al. Age is not a contraindication for orthotopic liver transplantation: a single institution experience with recipients older than 75 years. Hepatology International. 2011; In press.

69. Thuluvath PJ, Guidinger MK, Fung JJ, et al. Liver transplantation in the United States, 1999-2008. Am J Transplant. 2010; 10: 1003-1019.

70. Selzner M, Kashfi A, Selzner N, et al. Recipient age affects long-term outcome and hepatitis $\mathrm{C}$ recurrence in old donor livers following transplantation. Liver Transpl. 2009; 15(10): 1288-95.

71. Randall HB, Cao S, deVera ME. Transplantation in elderly patients. Arch Surg. 2003; 138(10): 1089-92.

72. Zetterman RK, Belle SH, Hoofnagle JH, et al. Age and liver transplantation: a report of the Liver Transplantation Database. Transplantation. 1998; 66(4): 500-6

73. Lencioni R, Crocetti L. Image-guided ablation for hepatocellular carcinoma. Recent Results Cancer Res. 2013; 190: 181-94.

74. Nishikawa H, Osaki Y, Iguchi E, et al. Radiofrequency ablation for hepatocellular carcinoma: the relationship between a new grading system for the ablative margin and clinical outcomes. J Gastroenterol 2012;Epub ahead of print.

75. Nishikawa H, Inuzuka T, Takeda H, et al. Percutaneous radiofrequency ablation therapy for hepatocellular carcinoma: a proposed new grading system for the ablative margin and prediction of local tumor progression and its validation. J Gastroenterol 2011; 46(12): 1418-26.

76. Shiina S, Tateishi R, Arano T, et al. Radiofrequency ablation for hepatocellular carcinoma: 10-year outcome and prognostic factors. Am J Gastroenterol 2012; 107(4): 569-77.

77. Tateishi R, Shiina S, Teratani T, et al. Percutaneous radiofrequency ablation for hepatocellular carcinoma. An analysis of 1000 cases. Cancer 2005; 103(6): 1201-9.

78. Tiong L, Maddern GJ. Systematic review and meta-analysis of survival and disease recurrence after radiofrequency ablation for hepatocellular carcinoma. Br J Surg 2011; 98(9): 1210-24.

79. Morimoto M, Numata K, Kondou M, et al. Midterm outcomes in patients with intermediate-sized hepatocellular carcinoma: a randomized controlled trial for determining the efficacy of radiofrequency ablation combined with transcatheter arterial chemoembolization. Cancer 2010; 116(23): 5452-60.

80. Fujii H, Itoh Y, Ohnishi N, et al. Factors associated with the overall survival of elderly patients with hepatocellular carcinoma. World J Gastroenterol 2012; 18: 1926-1932

81. Lencioni R. Chemoembolization for hepatocellular carcinoma. Semin Oncol. 2012; 39(4): 503-9.

82. Takayasu K, Arii S, Ikai I, et al; Liver Cancer Study Group of Japan. Prospective cohort study of transarterial chemoembolization for unresectable hepatocellular carcinoma in 8510 patients. Gastroenterology 2006; 131: 461-9.

83. Matsui O. Current status of hepatocellular carcinoma treatment in Japan: transarterial chemoembolization. Clin Drug Investig 2012; 32 Suppl 2:3-13.

84. Matsui O, Miyayama S, Sanada J, et al. Interventional oncology: new options for interstitial treatments and intravascular approaches: su- perselective TACE using iodized oil for HCC: rationale, technique and outcome. J Hepatobiliary Pancreat Sci 2010; 17(4): 407-9.

85. Yamada R, Sato M, Kawabata M, et al. Hepatic artery embolization in 120 patients with unresectable hepatoma. Radiology 1983; 148(2): 397-401.

86. Takayasu K. Transarterial chemoembolization for hepatocellular carcinoma over three decades: current progress and perspective. Jpn J Clin Oncol 2012; 42(4): 247-55.

87. Takayasu K, Arii S, Kudo M, et al. Superselective transarterial chemoembolization for hepatocellular carcinoma. Validation of treatment algorithm proposed by Japanese guidelines. J Hepatol 2012; 56(4): 886-92.

88. Ikeda K, Kumada H, Saitoh S, et al. Effect of repeated transcatheter arterial embolization on the survival time in patients with hepatocellular carcinoma. An analysis by the Cox proportional hazard model. Cancer 1991; 68 (10): 2150-4

89. Mondazzi L, Bottelli R, Brambilla G, et al. Transarterial oily chemoembolization for the treatment of hepatocellular carcinoma: a multivariate analysis of prognostic factors. Hepatology. 1994; 19(5): 1115-23.

90. Golfieri R, Bilbao JI, Carpanese L, et al. Comparison of the survival and tolerability of radioembolization in elderly versus younger patients with unresectable hepatocellular carcinoma. J Hepatol. 2013; doi:10.1016/j.jhep.2013.05.025.

91. Nishikawa H, Osaki Y, Kita R, et al. Hepatic Arterial Infusion Chemotherapy for Advanced Hepatocellular Carcinoma in Japan. Cancers 2012; 4: $165-83$.

92. Llovet JM, Ricci S, Mazzaferro V, et al; SHARP Investigators Study Group. Sorafenib in advanced hepatocellular carcinoma. N Engl J Med 2008; 359: 378-90.

93. Cheng AL, Kang YK, Chen Z, et al. Efficacy and safety of sorafenib in patients in the Asia-Pacific region with advanced hepatocellular carcinoma: a phase III randomised, double-blind, placebo-controlled trial. Lancet Oncol 2009; 10: 25-34.

94. Kudo M, Tateishi R, Yamashita T, et al. Current status of hepatocellular carcinoma treatment in Japan: case study and discussion-voting system. Clin Drug Investig 2012; 32 Suppl 2: 37-51.

95. Kudo M, Ueshima K, Arizumi T. Real-life clinical practice with sorafenib in advanced hepatocellular carcinoma: a single-center experience. Dig Dis 2012; 30(6): 609-16.

96. Wong H, Tang YF, Yao TJ, et al. The outcomes and safety of single-agent sorafenib in the treatment of elderly patients with advanced hepatocellular carcinoma (HCC). Oncologist. 2011; 16(12): 1721-8.

97. Di Costanzo GG, Tortora R, De Luca M, et al. Impact of age on toxicity and efficacy of sorafenib-targeted therapy in cirrhotic patients with hepatocellular carcinoma. Med Oncol. 2013; 30(1): 446.

98. Montella L, Addeo R, Cennamo G, et al. Sorafenib in elderly patients with advanced hepatocellular carcinoma: a case series. Oncology. 2013; 84(5): 265-72.

99. Abou-Alfa GK, Schwartz L, Ricci S, et al. Phase II study of sorafenib in patients with advanced hepatocellular carcinoma. J Clin Oncol 2006; 24: $4293-300$

100. Baek KK, Kim JH, Uhm JE, et al. Prognostic Factors in Patients with Advanced Hepatocellular Carcinoma treated with Sorafenib: A Retrospective Comparison with Previously Known Prognostic Models. Oncology 2011; 80: 167-74.

101. Llovet JM, Peña CE, Lathia CD, et al; on behalf of the SHARP Investigators Study Group: Plasma Biomarkers as Predictors of Outcome in Patients with Advanced Hepatocellular Carcinoma. Clin Cancer Res 2012; 18: $2290-300$

102. Takeda H, Nishikawa H, Iguchi E, et al. Sorafenib-induced acute interstitial pneumonia in patients with advanced hepatocellular carcinoma: report of three cases. Clin J Gastroenterol 2012; 5: 407-12.

103. Takeda H, Nishikawa H, Iguchi E, et al. Impact of pretreatment serum cholinesterase level in unresectable advanced hepatocellular carcinoma patients treated with sorafenib. Mol and Clin Oncol 2013; 1: 241-48.

104. Nishikawa H, Osaki Y, Iguchi E, et al. Comparison of the efficacy of transcatheter arterialchemoembolization and sorafenib for advanced hepatocellular carcinoma. Exp Ther Med 2012; 4(3): 381-6.

105. Ikeda M, Mitsunaga S, Shimizu S, et al. Efficacy of sorafenib in patients with hepatocellular carcinoma refractory to transcatheter arterial chemoembolization. J Gastroenterol.. 2013; [Epub ahead of print]

106. Morimoto M, Numata K, Kondo M, et al. Higher discontinuation and lower survival rates are likely in elderly Japanese patients with advanced hepatocellular carcinoma receiving sorafenib. Hepatol Res. 2011; 41(4): 296-302. 